\title{
AKUNTANSI MANAJEMEN DALAM PRESPEKTIF STRATEGI KEUNGGULAN BERSAING
}

\author{
oleh : Ahmad Fahrudin A \\ Jurusan Akuntansi Universitas Islam Negeri Maulana Malik Ibrahim Malang \\ e-mail : afahrudin.feuin@gmail.com \\ HP : 08123393789
}

\begin{abstract}
Dynamics business makes strategic outlook as an important paradigm in management accounting. Contemporary management accounting is ineligible to occupy only the calculation of costs and decision-making regardless of environmental factors that move fast. By combining competitive strategy, management accounting tools are expected to support the role of strategic choice taken by firm. This article discusses how far management accounting can play an active role to create a competitive advantage in the competitive business.
\end{abstract}

Keyword: Akutansi manajemen, strategi, otomatisasi, keunggulan.

Tantangan strategis bagi akuntansi manajemen adalah usahanya dalam mencapai posisi keunggulan bersaing di era global. Akuntansi manajemen seharusnya tidak hanya menyibukkan pada rincian kalkulasi dan kendali biaya saja, sehingga mengorbankan keterlibatannya secara lebih besar dalam pembuatan keputusan dan pengukuran strategis (Cowe 1993:13). Pergerakan bisnis yang sangat dinamis menjadikan pada akuntan manajemen harusnya membuka pandangannya keluar, dan bukannya menutup jendela pasar yang harusnya mereka amati. Munculnya pasar global dengan tingkat kompetensi yang tinggi, perubahan bisnis yang cepat, menjadikan kebutuhan akan akuntansi manajemen yang tepat waktu (timely current) dan informasi masa depan menjadi meningkat (Welfe \& Keltyka 2000).

Artikel ini akan membahas sejauhmana peran akuntansi manajemen dalam menciptakan keunggulan bersaing melalui alat-alat kontemporer yang banyak diterapkan di berbagai negara di dunia dan terbukti sukses. Sedikit banyak akan diulas mengenai pilihan strategi bisnis yang akan dikaitkan dengan upaya akuntansi manajemen mencapai keunggulan bersaing. 


\section{STRATEGI BISNIS DAN AKUNTANSI MANAJEMEN}

Dinamika lingkungan bisnis yang begitu cepat, menjadikan manajemen tidak hanya berfikir secara internal, mau tidak mau mereka harus berfikir secara komprehensif melalui pilihan-pilihan strategis. Strategi didefinisikan sebagai seperangkat tindakan dalam menjamin tercapainya keunggulan bersaing (Ashton et. al. 1995). Beberapa penulis membagi strategi dalam tiga level yaitu :

1. Corporate strategy. Berkaitan dengan alokasi sumber daya di antara berbagai bisnis atau divisi suatu perusahaan.

2. Business strategy. Berada pada level bisnis-bisnis tertentu atau divisi dalam mencapai keunggulan kompetitif

3. Fuctional strategy. Terletak pada level tindakan yang spesifik pada tiaptiap bagian bisnis (contoh: distribusi).

Orientasi pembahasan kita terletak pada level strategi bisnis, yang kemudian dihubungkan dengan pemikiran strategi bersaing. Porter (1994) mendefiniskan strategi bersaing dalam generic strategy yang tergambarkan di bawah ini:

KEUNGGULAN BERSAING

\begin{tabular}{|c|c|c|}
\hline & Biaya rendah & Diferensiasi \\
\hline $\begin{array}{l}\text { sasaran } \\
\text { luas }\end{array}$ & $\begin{array}{c}\text { 1. Keunggulan } \\
\text { Biaya }\end{array}$ & 2. Diferensiasi \\
\hline $\begin{array}{c}\text { sasaran } \\
\text { sempit }\end{array}$ & $\begin{array}{l}\text { 3B. Fokus } \\
\text { Diferensial }\end{array}$ & 3A. Fokus Biaya \\
\hline
\end{tabular}

Gambar 1: Tiga Strategi Generik (Porter 1994:12)

\section{Cost Leadership}

Keunggulan biaya akan tercapai dengan pencapaian produk berbiaya rendah. Upaya ini dilakukan dengan teknik-teknik reduksi biaya yang sangat relevan 
dengan alat-alat manajemen kontemporer yang secara garis besar tergambar dalam "strategic cost management". Produsen berbiaya rendah biasanya menjual produk standar dengan harga sama atau lebih rendah dari harga pasar. Orientasi memandang pasar ini penting dalam mencapai target margin laba yang diharapkan (maximizing profit), meskipun kadang hal ini tidak bisa lepas dari strategi diferensiasi. Sangat penting untuk memadukan antara pilihan diferensiasi dan cost leadership dalam mencapai kinerja perusahaan di atas ratarata pesaingnya.

\section{Differensiasi}

Perusahaan harus menjadi unik dalam industrinya pada atribut-atribut produk yang penting (relevan) di mata pelanggan. Ciri khas produk, keunggulan mutu, akan menciptakan segmen customer tersendiri, bahkan apabila perusahaan mengkombinasikan dengan strategi cost reduction, akan tercapai kinerja produk di atas rata-rata pesaing. Caranya dengan mengurangi biaya tanpa mengurangi nilai diferensiasi produk.

\section{Fokus}

Perusahaan tidak lagi mengkombinasikan antara cost leadership dan differentiation tapi sudah berfokus pada salah satunya. Pilihan ini bisa saja terjadi dengan membidik pangsa pasar tertentu, misalnya: membuat produk subtitusi dengan harga murah untuk merebut segmen masyarakat kelas bawah (cost reduction) atau membuat produk dengan keunikan dan kualitas tersendiri meskipun harga di atas pesaing rata-rata dalam membidik konsumen kelas atas (differensiasi).

\section{Strategic Management Accounting dan Strategic Cost Management: Implikasi}

\section{Orientasi Strategis dalam Bisnis}

Dari pandangan strategis di atas, apabila dimasukkan dalam konteks akuntansi manajemen. akan terbentuklah pandangan akuntansi manajemen berwawasan keunggulan bersaing, seperti yang diungkapkan oleh Richard M.S. Wilson : 
Strategic management accounting is an approach to management accounting that explicitly highlights strategic issues and concerns.

It sets management accounting in broader context in which financial information is used to develop superior strategies as a means of achieving sustainable competitive advantage (Ashton et. al. 1995:162)

Berkaitan konsep tersebut, terbentuklah suatu pemikiran-pemikiran yang berujung terciptanya alat-alat akuntansi manajemen strategis. Penjelasan mengenai alat-alat akuntansi manajemen dan beberapa implikasi penerapan teknologi baru akan di bahas pada bagian lain pada artikel ini.

Variasi dari strategic management accounting adalah strategic cost management yang didefinisikan oleh Hansen \& Mowen (1997:354) sebagai penggunaan data biaya untuk mengembangkan dan mengidentifikasi strategi yang unggul dalam mendukung tercapainya keunggulan bersaing. Dari maksud tersebut, dapat dianalisis bahwa strategic cost management merupakan alat pendukung strategic management accounting. Shank \& Govindarajan (1993:8) mengkaitkan strategic cost management dengan tiga konsep berikut:

1. Value Chain Analysis

2. Strategic Positioning analysis

3. Cost Driver Analysis

Analisis rantai nilai terkait dengan pengidentifikasikan hubungan internal dan eksternal pada perusahaan dalam pencapaian strategi cost leadership dan differentiation(atau pendukung keunggulan bersaing). Eksploitasi hubungan ini dilakukan dengan analisa "bagaimana biaya dan faktor non-financial lainnya memberikan dampak pada aktivitas dalam rantai produk. Penentuan posisi strategis terkait dengan pilihan strategis yang dipakai apakah cost leadership ataukah differentiation. Perbedaan orientasi ini akan berdampak signifikan pada teknik manajemen biaya yang dilakukan. Analisa cost driver adalah pemilihan cost driver yang sesuai dengan orientasi strategis. Penekanan ini akan memindahkan orientasi analisis strategic cost driver dari volume menuju cost driver lain misalnya Activity-Based Costing dengan driver aktivitas, atau penggunaan structural cost driver (Scherer 1980 dalam Shank \& Govindarajan 1993:20). 


\section{ALAT AKUNTANSI MANAJEMEN DALAM MENCAPAI KEUNGGULAN BERSAING}

\section{Management Accounting and Technology Implication}

Teknologi otomatisasi merupakan sarana pendukung untuk mencapai keunggulan bersaing. Tentunya teknologi yang dibuat akan bisa membawa 2 dimensi strategis yaitu biaya rendah dan/atau kualitas unggul. Penggunaan teknologi yang canggih dengan cara-cara yang tepat telah banyak diterapkan di Jepang. Respon strategis akan bisa dicapai melalui penggunaan teknologi manufaktur yang fleksibel (Flexible Manufacturing Systems--FMS) sesuai dengan apa yang dikehendaki konsumen. Penelitian Jaikumar (1986) mengindikasikan bahwa penggunaan FMS di Jepang lebih efisien dengan indikasi rasio utilisasi mesin (untuk perusahaan metal-cutting), jumlah produksi per-sistem, tipe produk, jauh lebih besar daripada yang di Amerika. Di Amerika, perusahaan kurang fleksibel dalam menata teknologi manufakturnya, sehingga berdampak pada variasi produk yang kurang, kurangnya optimalisasi pemanfaatan mesin yang kesemuanya ini akan menurunkan kemampuan bersaing.

Elemen kunci penggunaan FMS terbagai 3 yaitu (1)Automatic material handling (2)Semi-independent work station (3)A network of supervisory computers (Foster \& Horngren 1998). 3 kunci ini menuntut penerapan teknologi yang canggih dan tepat yang tentunya akan berimplikasi pada penggunaan akuntansi manajemen dan akuntansi biaya yang mendukung. Beberapa implikasi yang akan terjadi adalah: persediaan yang rendah, berkurangnya biaya tenaga kerja langsung, pengurangan adanya scrap $\mathcal{E}$ rework, dan tentunya penghematan tempat. Perubahan tersebut tentunya dalam skala strategi merupakan suatu hal yang bermanfaat dan perlu ditindaklanjuti dengan metode akuntansi biaya yang cocok.

\section{Activity Based Cost-System (ABC-System)}

Pergesaran otomatiasi produksi, cenderung menjadikan komponen biaya overhead menjadi semakin besar. Biaya tenaga kerja menjadi semakin kecil, sehingga kebutuhan akan sistem ABC memang benar-benar diperlukan. Sistem 
ABC selain mampu lebih akurat menentukan biaya yang memang terkait dengan produk-dengan dasar alokasi aktivitas, juga memotivasi manajer untuk memaksimalkan pemanfaatan kapasitas sumberdaya yang ada (karena pada banyak komponen overhead bersifat tetap).

Sistem ABC mengestimasi biaya atas sumberdaya yang digunakan pada proses organisasi dalam memproduksi output. Persamaan berikut mendifinisikan tiap aktivitas utama yang dibentuk sumber daya organisasi yang diformulasikan sebagai berikut (Cooper \& Kaplan 1992)

Aktivitas yang tersedia $=$ aktivitas penggunaan + kapasitas tidak digunakan

Atau

\section{Cost activity supplies $=$ cost of activity uses + cost of unused activity}

Informasi penggunaan sumberdaya $\mathrm{ABC}$ bisa digunakan manajer untuk memonitor dan memprediksi perubahan dalam permintaan atas aktivitas sebagai fungsi dari perbedaan dalam volume output dan baurannya, perubahan proses dan perbaikannya, perkenalan teknologi baru, dan perubahan desain produk dan prosesnya. Saat beberapa perubahan direnungkan, manajer bisa memprediksi saat terjadinya kekurangan atau kelebihan atas kapasitas yang terjadi. Manajer juga bisa memodifikasi keputusannya sehingga permintaan aktivitas akan dibawa pada keseimbangannya dengan supply, atau mereka bisa menjadikannya benar-benar tersedia pada periode mendatang.

Karenanya, pengukuran biaya atas sumberdaya yang disediakan (cost of resources supplied) mengindikasikan pada manajer, suatu tingkat pengeluaran yang terjadi (atau umumnya sebagai beban) dan kapasitas untuk membentuk aktivitas dimana pengeluaran itu tersedia.

ABC system mengestimasi biaya atas sumberdaya yang digunakan dengan basis aktivitas yang dilakukan ditinjau dari berbagai output yang bervariasi. Model ABC sebenarnya merupakan alokasi biaya overhead dengan basis aktivitasnya dalam rangka meningkatkan nilai tambah suatu produk. 
Pengukuran dilakukan dengan menentukan aktivitas apa yang terjadi, apa pemicunya (driver), sehingga dasar penentuan tarifnya menjadi lebih tepat, karena drivernya cocok dengan aktivitas yang ada.

Berikut ini contoh model ABC dalam alokasinya:

\begin{tabular}{|l|c|c|}
\hline \multicolumn{1}{|c|}{ Activity } & People & Total Cost \\
\hline Penerimaan pembelian komponen & 4 & $\$ 250,000$ \\
\hline Penerimaan bahan baku & 3 & $\$ 125,000$ \\
\hline Pemakaian bahan & 3 & $\$ 125,000$ \\
\hline
\end{tabular}

Pada tahun tersebut, perusahaan menerima 25,000 kiriman atas pembelian komponen, dan 10,000 kiriman bahan baku. Aktivitas produksi berjalan 5000 production run.Jadi untuk alokasi biayanya berdasarkan $\mathrm{ABC}$ adalah:

\begin{tabular}{|c|c|c|}
\hline Activity & Allocation Measure & Unit Cost \\
\hline Penerimaan pembelian komponen & Jumlah kiriman per tahun & $\$ 10$ per kiriman \\
\hline Penerimaan bahan baku & Jumlah kiriman per tahun & $\begin{array}{l}\$ \quad 12.5 \quad \text { per } \\
\text { kiriman }\end{array}$ \\
\hline Pemakaian bahan & Jumlah production run & $\$ 25$ per run \\
\hline
\end{tabular}

Dasar alokasi tersebut dianggap lebih akurat, karena mencerminkan kondisi sebenarnya (banyak kategori yang bisa dipakai misalnya: Unit Level Activity, Batch Level Activity, Product Level Activity, dan Facility sustaining Activity tergantung jenis aktivitas pada perusahaannya).

Efek ABC terhadap kebijakan perusahaan cukup besar karena pendekatan ini lebih berpengalaman dalam mengalokasikan factory overhead, corporate overhead, dan sumberdaya organisasi. Biaya overhead manufaktur akan terinci secara jelas, berapa kapasitas tersedia, berapa kapasitas yang terpakai, dan tidak terpakai, yang nantinya akan menjadi alat analisis yang baik bagi manajer disamping penentuan cost yang lebih tepat. 


\section{Just-In-Time (JIT)}

Filosofi JIT secara umum sebenarnya difokuskan pada pembentukan aktivitas saat dia itu benar-benar diperlukan dalam segmen internal organisasi. Jadi di sini ditekankan adanya ketepatan waktu, ketepatan order, ketepatan proses, ketepatan jumlah dll. Menurut Foster \& Horngren dalam Brinker (1990:1999) filosofi JIT diharapkan akan:

1. Mengeliminasi aktivitas yang tidak bernilai tambah (misalnya: penyimpaan persediaan)

2. Menciptakan komitmen kualitas pada setiap mata rantai produk

3. Meciptakan perbaikan berkelanjutan atas efisiensi aktivitas

4. Mempermudah dalam menentukan aktivitas yang bernilai tambah

JIT sendiri bisa terbagi dalam beberapa segmen fokus misalnya: JIT Purchasing, JIT Production, JIT Distribution, JIT Retailing, atau JIT Administrative. Penerapan dari tiap-tiap fokus itu akan berimplikasi pada perubahan sistem akuntansi yang berkenaan dengannya. Oleh karenanya banyak sekali pertimbangan yang akan dilakukan di antaranya adalah :

1. Pertimbangan biaya dan manfaat atas perubahan sistem akuntansi manajemen yang akan dilakukan

2. Keterkaitan antara product costing and control system

3. Informasi-informasi control dari tiap-tiap sistem akuntansi produk

4. Berbagai informasi tambahan yang diperlukan oleh manajemen

Dari sisi manajemen biaya, JIT merupakan suatu prespektif strategis yang bisa diusahakan memberikan manfaat cost reduction secara signifikan. Berikut ini contoh aplikasi JIT pada JIT production dengan menekankan pada "pull through system".

\section{JIT-Production}

Praktek ini menekankan pada lingkungan produksi, dimana tiap komponen diproduksi sesuai yang dibutuhkan oleh bagian/step selanjutnya pada lini produksi. Karakteristik JIT production adalah:

1. Lini produksi berjalan pada demand-pull basis 
2. Titik berat pada pengurangan waktu tunggu (lead time)

3. Lini produksi berhenti saat produk dalam proses tidak sempurna

4. Aktivitas non-value added bisa kelihatan jelas, karena tekanan produksi hanya pada lini produk saja.

Implikasi akuntansi yang akan dialami adalah:

1. Tingkat kemampuan penelusuran direct cost semakin tinggi, karena fokus JIT terletak pada aktivitas produksi yang spesifik pada lini produk tertentu

2. Mengurangi penitikberatan pada varian tenaga kerja dan overhead individual

3. Mengurangi pencatatan yang detail pada informasi kartu pekerjaan dengan hanya mencantumkan bahan langsung saja, atau penggunaan backflush costing.

\section{Backflush Costing}

Sistem ini difokuskan pertama kali pada output dan kemudian bergerak mundur ketika mengaplikasikan biaya per unit yang dijual atau pada persediaan. Asumsi ini terjadi karena penjurnalan biaya berkenaan produk dapat ditunda sampai dengan produk tersebut dijual, atau saat biaya terakhir dibebankan pada sistem akuntansi. Berbeda dengan sistem tradisional dimana costing dimulai sejak pembebanan bahan baku ke WIP dan seterusnya.

\section{Konklusi}

Tidak ada pedoman tunggal mengenai implikasi praktek JIT dalam akuntansi biaya dan manajemen biaya, apakah itu cost pool, dasar alokasi, sistem costing, atau pengukuran kinerja. Namun kesemua itu sebenarnya menuju penyederhanaan praktek akuntansi biaya, dengan adanya penyederhanaan aktivitas (aktivitas non-value added dihilangkan).

\section{Life Cycle Cost Management (LCCM)}

LCCM terkait dengan dengan bangunan kerangka konseptual yang menghubungkan antara rantai internal dan eksternal. Dalam prespektif strategis, 
konsep ini sangat terkait dengan value-chain analysis dengan acuan atas daur hidup produk yang berkaitan. Konsep LCCM merupakan turunan dari padangan marketing tentang product life cycle yang kemudian menjadi pandangan produksi tentang life-cycle costing. Lebih jelasnya tergambarkan pada gambar

\section{Gambar 2: Hubungan antara Marketing dan}

Produk Stages of Product Life Cyle (Susman dalam Brinker 1990:229)

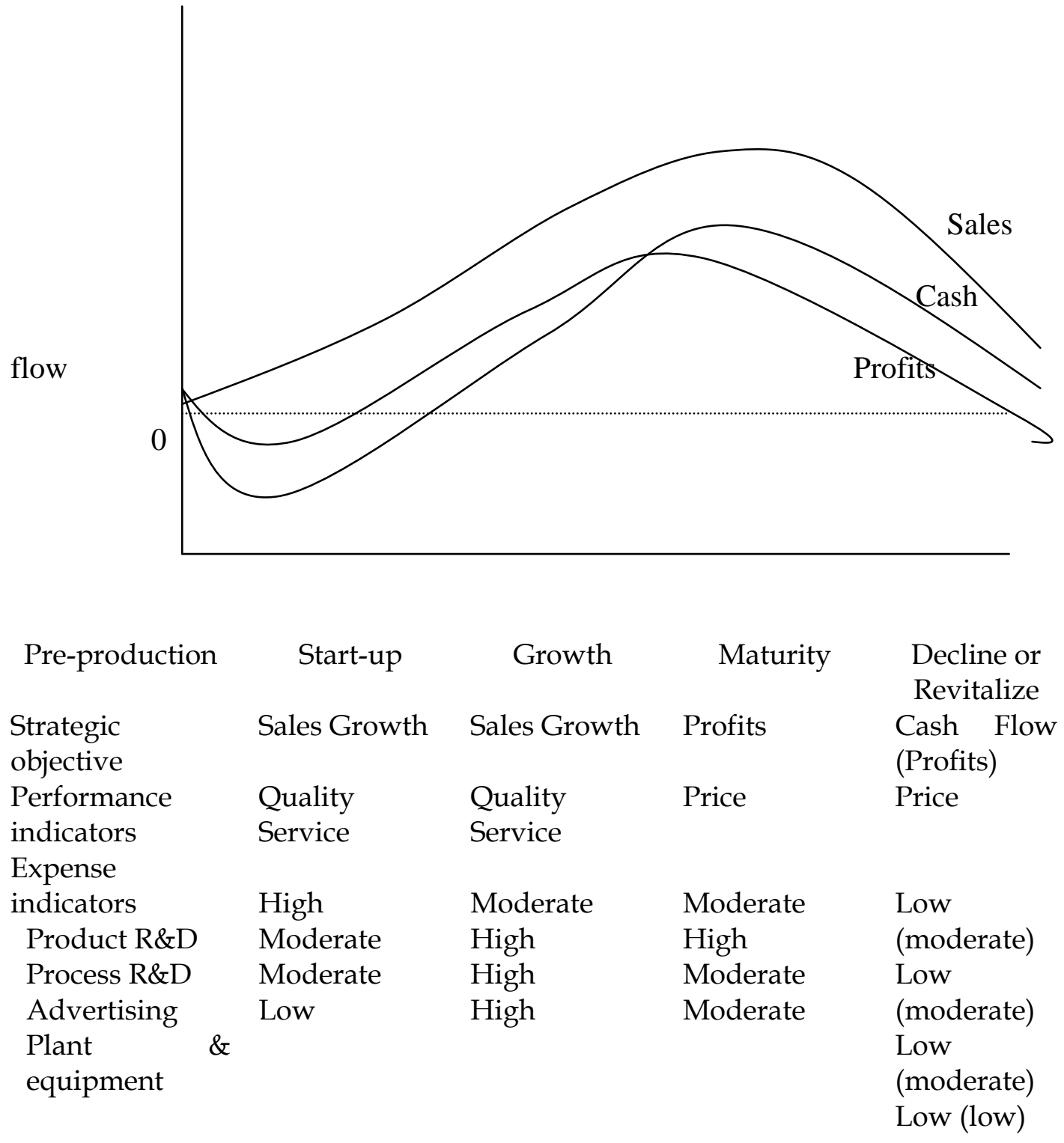


Dengan mengacu pada gambar 2, prespektif akuntansi manajemen yang bisa diambil akan terkait dengan strategic cost management, yaitu "revenue-viewsoriented" dan "expense oriented viewpoints". Pada konsep strategi harga, misalnya: saat stage introduction, harga bisa dinaikkan karena tingkat sensitivitas harga bagi konsumen relatif rendah dan mereka lebih tertarik dengan performance (Hansen \& Mowen 1997:369). Namun saat produk dalam kondisi maturity sensitivitas harga dan performance sangatlah tinggi, sehingga perlu adanya strategi differensiasi dengan meningkatkan kualitas produk, servis, garansi, sehingga produk dapat bersaing dengan pesaingnya.

Strategi cost reduction yang dipakai dengan mengacu pada LCCM adalah dengan memandang dari tiap stage cycle-nya. Permulaan yang penting bisa menjadi dasar untuk daur hidup selanjutnya, semisal saat mendesain produk yang dengan biaya produksi, logistik, dan postpurchase yang bisa ditekan. Ini akan berimplikasi pada stage-stage selanjutnya.

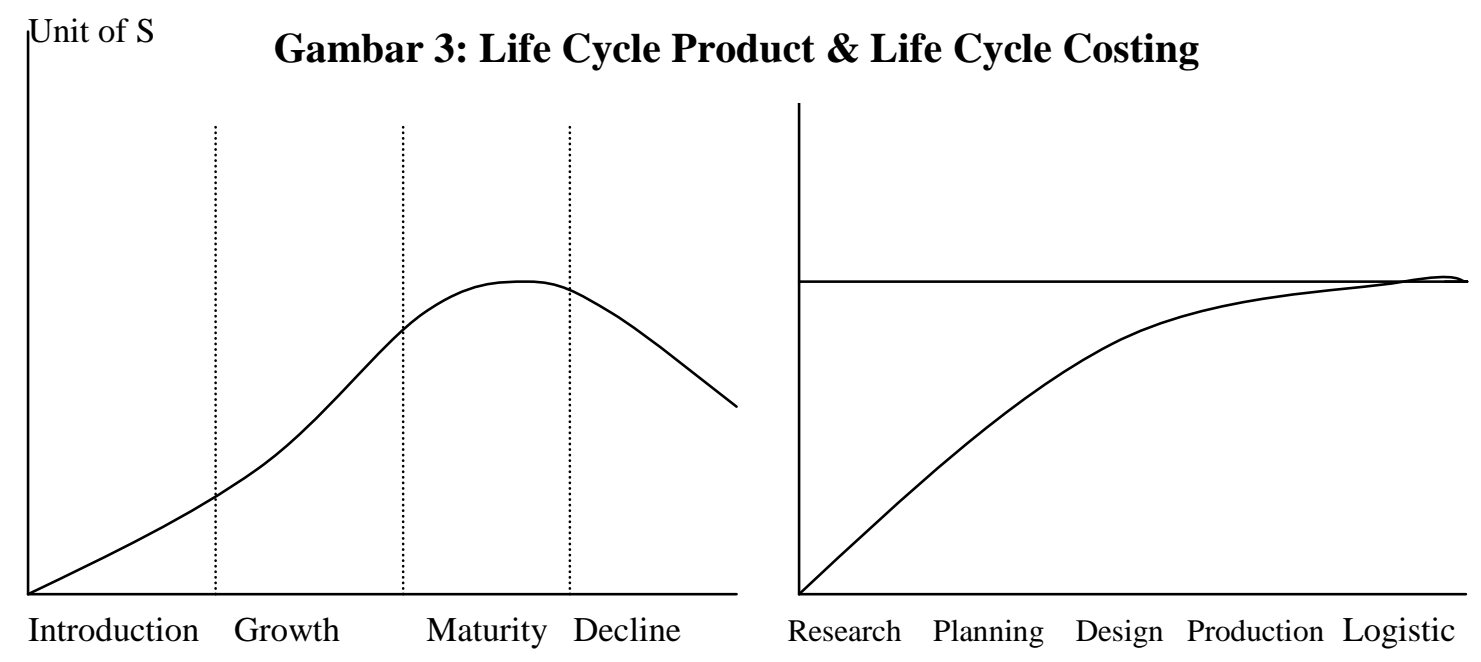

Pemahaman tentang daur hidup produk akan menjadikan analisa akuntansi manajemen tidak akan terhenti pada titik yang terlalu cepat. Analisa ini secara lebih jauh juga menganalisa mengenai biaya-biaya yang berkenaan setelah 
produk itu dijual, sehingga dalam prespektif "mencapai keunggulan bersaing" konsep ini sangat cocok diterapkan.

\section{PENUTUP}

Strategi bisnis terbagi dalam tiga konsep yaitu cost reduction, differentiation, dan focus. Implikasi pilihan strategi ini akan berdampak pada pilihan alat akuntansi manajemen dan secara mendasar terhadap keputusan strategic cost management. Konsep strategis menjadikan akuntansi manajemen lebih membuka pandangan ke luar tentang pentingnya analisis rantai nilai, analisis posisi strategis, serta analisis cost driver.

Peran akuntansi manajemen ditunjukkan melalui berbagai alat (tools) yang mendukung tercapainya keunggulan bersaing, baik itu bersifat filosofis maupun teknis. Teknolgi manufaktur yang maju perlu dipraktekkan dalam usaha tepat guna melalui flexible manufacturing system-sebuah teknik yang mampu memberikan efisiensi yang besar atas proses manufaktur. Tentunya teknologi ini akan didukung alat akuntansi biaya yang memadai. Sebuah implikasi atas otomatisasi dengan meningkatnya biaya overhead secara signifikan, menjadikan perlunya dibuat teknik costing yang mumpuni yaitu Activity Based Costing (ABC). ABC selain mampu membebankan biaya secara akurat (berbasis aktivitas), namun juga bisa dipakai sebagai pedoman eliminasi aktivitas tidak bernilai tambah.

Filosofi Just-in-Time (JIT) dikembangkan dalam usaha mengeliminasi aktivitas tidak bernilai tambah, misalnya penyimpanan persediaan dan waktu tunggu. Implikasi pada akuntansi manajemen strategis sangat besar mengingat 
selain untuk cost reduction, filosofi JIT menganut "total quality management" sehingga setiap penyimpangan kualitas akan diketahui langsung. Teknik ini bisa dipakai baik dalam strategi cost reduction, differensiasi, ataupun fokus.

Aktivitas produk ternyata tidak hanya saat produk itu diproduksi dan laku dijual. Biaya produk akan terjadi saat produk itu mulai di desain, diproduksi, hingga setelah laku dijual. Filosofi bahwa setelah produk laku dijual menunjukkan bahwa tanggujawab manajemen selesai sungguh tidak tepat, mengingat nilai produk ternyata sangat tergantung dari konsumennya. Analisis life cycle cost sangat erat kaitannya dengan konsep value chain analysis dalam strategi bersaing. Pilihan-pilihan strategi bisa dilakukan dari tiap-tiap stage daur hidup produk.

Masih banyak alat akuntansi manajemen yang lain, yang mampu mendukung tercapainya keunggulan bersaing. Pembahasan artikel ini masih dibatasi pada konsep-konsep tataran teoritis dengan pilihan-pilihan topik di atas. Akan lebih baik bila diteruskan dengan pembahasan poin-per-poin mengenai aplikasi dari tiap-tiap topik dalam akuntansi manajemen. 


\section{Referensi:}

Ashton, David, Trevor Hopper, Robert W. Scapens, 1992, Issues in Management Accounting, Prentice Hall International: Maylands UK

Brinker, Barry J., 1990, Emerging Practices in Cost Management, Warren, Gorham, \& Lamont: Boston

Cooper, Robin, \& Robert S. Kaplan, 1992, Activity-Based System: Measuring the Costs of Resource Usage, Accounting Horizon-September,

Cowe, Robert, 1993, Seri Pedoman Manajemen Akuntansi (edisi terjemahan), PT Elex Media Komputindo: Jakarta

Foster, George, \& Charles T. Horngren, 1988, Flexible Manufacturing System, Journal of Management and Manufacturing Industry,

Hansen, Don R. \& Maryanne M. Mowen, 1997, Cost Management: Accounting and Control, International Thomson Publishing. Cincinnati-Ohio

Jaikumar, Ramchandran, 1986, Post Industrial Manufacturing, Harvard Business Review-November-December,

Porter, Michael, 1993, Keunggulan Bersaing (edisi terjemahan), PT Binarupa Aksara: Jakarta

Shank, John K., \& Vijay Govindarajan, 1993, Strategic Cost Management: The New Tool for Competitive Advantage, The Free Press: New York 